\title{
Increased intracellular calcium concentration causes electrical turbulence in guinea pig ventricular myocytes
}

\author{
FAN XinRong ${ }^{1,3}$, MA JiHua $^{1 *}$, WAN Wei ${ }^{1}$, ZHANG PeiHua ${ }^{1}$, WANG Chao ${ }^{1} \&$ WU Lin $^{2}$ \\ ${ }^{1}$ Cardio-Electrophysiological Research Laboratory, Medical College of Wuhan University of Science and Technology, Wuhan 430081, China; \\ ${ }^{2}$ Department of Biology, Gilead Sciences, Inc., Palo Alto, California 94304, USA; \\ ${ }^{3}$ Department of Cardiology, Renmin Hospital of Wuhan University, Wuhan 430060, China
}

Received July 6, 2010; accepted December 21, 2010

\begin{abstract}
Dysregulation of intracellular $\mathrm{Ca}^{2+}$ homeostasis is associated with various pathological conditions and arrhythmogenesis of the heart. The objective of this study was to investigate the effects of an acute increase in intracellular $\mathrm{Ca}^{2+}$ concentration $\left(\left[\mathrm{Ca}^{2+}\right]_{\mathrm{i}}\right)$ on the electrophysiology of ventricular myocytes by mimicking intracellular $\mathrm{Ca}^{2+}$ overload. The $\left[\mathrm{Ca}^{2+}\right]_{\mathrm{i}}$ was clamped to either a controlled $\left(65-100 \mathrm{nmol} \mathrm{L}{ }^{-1}\right)$ or increased $\left(1 \mu \mathrm{mol} \mathrm{L}{ }^{-1}\right)$ level. The transmembrane action potentials and ionic currents were recorded using whole-cell patch clamp techniques. We found that the acute increase in $\left[\mathrm{Ca}^{2+}\right]_{\mathrm{i}}$ shortened the action potential duration, reduced the action potential amplitude, maximum depolarization velocity and resting membrane potential, caused delayed after-depolarizations (DADs), and triggered activity-compared with these parameters in the control. The increased $\left[\mathrm{Ca}^{2+}\right]_{\mathrm{i}}$ augmented late $I_{\mathrm{Na}}$ in a time-dependent manner, reduced $I_{\mathrm{CaL}}$ and $I_{\mathrm{K} 1}$, and increased $I_{\mathrm{Kr}}$ but not $I_{\mathrm{Ks}}$. The results of this study can be used to explain calcium overload-induced ventricular arrhythmias.
\end{abstract}

intracellular calcium, arrhythmia, action potentials, ionic currents, cardiomyocytes

Citation: Fan X R, Ma J H, Wan W, et al. Increased intracellular calcium concentration causes electrical turbulence in guinea pig ventricular myocytes. Sci China Life Sci, 2011, 54: 240-247, doi: 10.1007/s11427-011-4146-1

The inorganic calcium ion $\left(\mathrm{Ca}^{2+}\right)$ is one of the most universal and important messengers in living cells and is responsible for signal transduction and regulation of vital functions [1]. The dysregulation of $\mathrm{Ca}^{2+}$ homeostasis increases intracellular calcium concentration $\left(\left[\mathrm{Ca}^{2+}\right]_{i}\right.$; i.e., intracellular $\mathrm{Ca}^{2+}$ overload) and is associated with various pathological conditions of the heart, including myocardial ischemia/reperfusion [2], heart failure [3], caffeine [4], digitalis intoxication [5], hypercalcinemia [6], and the proarrhythmic activity of drugs [7-9]. Increases in free oxygen species also result in intracellular $\mathrm{Ca}^{2+}$ overload and ventricular arrhythmogenesis $[10,11]$.

Cytosolic $\mathrm{Ca}^{2+}$ is normally about $10^{-7} \mathrm{~mol} \mathrm{~L}^{-1}$ in the resting condition and may rise to $10^{-5} \mathrm{~mol} \mathrm{~L}^{-1}$ at $1-5 \mathrm{~ms}$ after

*Corresponding author (email: mjhua@wust.edu.cn) after depolarization. In animal or human cardiomyocytes, intracellular $\mathrm{Ca}^{2+}$ overload is associated with initiation and maintenance of both atrial and ventricular arrhythmic activities, including fatal ventricular tachycardia and ventricular fibrillation $[7,11,12]$. The main mechanism of $\mathrm{Ca}^{2+}$-induced arrhythmias is alteration of the membranous ionic currents, which results in shortening the action potential duration (APD), reducing the effective refractory period (ERP), and making reentry easier [10,13].

Several pathological models have been used to investigate the effects of calcium overload on membrane currents, including elevated extracellular calcium concentration [6], increased intracellular sodium concentration [14], heart failure [15], myocardial ischemia/reperfusion [2], and use of drugs (caffeine [4] or digitalis [5]). In addition, some other research related to the mechanism of intracellular $\mathrm{Ca}^{2+}$-de- 
pendent signaling transduction, including CaMK-II $[15,16]$, Ras [17], and PKC [18,19], for example, have gained substantial progress in terms of channel currents. These pathological models of elevated $\left[\mathrm{Ca}^{2+}\right]_{\mathrm{i}}$ mimic the condition of calcium overload by a series of cellular reactions that may interfere with the effectiveness of the calcium overload. Therefore, some of the conclusions of these studies tend to be contradictory, which makes this issue even more controversial. As an example, it is difficult to tell whether the changes in action potential and various membrane currents were the result of the direct increase of intracellular $\mathrm{Ca}^{2+}$ or indirect intracellular physical and chemical reactions. In fact, models of calcium overload by direct elevation of $\left[\mathrm{Ca}^{2+}\right]_{i}$ have rarely been investigated.

We hypothesized that a direct increase in $\left[\mathrm{Ca}^{2+}\right]_{i}$ may also regulate membrane ion currents and is associated with ventricular arrhythmic activity in cardiomyocytes. Therefore, we established a model of acute calcium overload using a whole-cell path clamp technique; and we directly regulated $\mathrm{Ca}^{2+}$ concentration with a pipette solution to change the $\left[\mathrm{Ca}^{2+}\right]_{i}$. The effects of an acute increase in $\left[\mathrm{Ca}^{2+}\right]_{i}$ on action potentials and various membrane currents as well as ventricular arrhythmic activities were evaluated. Increased $\left[\mathrm{Ca}^{2+}\right]_{\mathrm{i}}$ was achieved at a concentration of $1 \mu \mathrm{mol} \mathrm{L} \mathrm{L}^{-1}$, up to about 10 -fold higher than the resting $\left[\mathrm{Ca}^{2+}\right]_{\mathrm{i}}[20]$.

\section{Materials and methods}

\subsection{Cardiomyocyte isolation}

The use of animals in this investigation conformed to the Guide for the Care and Use of Laboratory Animals Regulated by Administrative Regulation of Laboratory Animals of Hubei Province and was approved by the Experimental Animal Center of Wuhan University of Science and Technology. Guinea pigs of either sex, weighing 250-300 g, were anesthetized by intraperitoneal injection of $20 \%$ urethane $\left(1000 \mathrm{mg} \mathrm{kg}^{-1}\right)$. The heart was excised and retrogradely perfused in modified Langendorff mode with $\mathrm{Ca}^{2+}$-free Tyrode solution bubbled with $100 \% \mathrm{O}_{2}$ and maintained at $37^{\circ} \mathrm{C}$. The Tyrode solution contained $\left(\mathrm{mmol} \mathrm{L}^{-1}\right)$ : $135 \mathrm{NaCl}, 5.4 \mathrm{KCl}, 1 \mathrm{MgCl}_{2}, 0.33 \mathrm{NaH}_{2} \mathrm{PO}_{4}, 10$ HEPES,

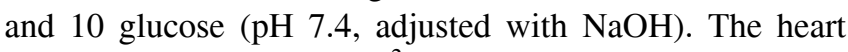
was then perfused with $\mathrm{Ca}^{2+}$-free Tyrode solution containing collagenase type $\mathrm{I}\left(0.2 \mathrm{mg} \mathrm{mL}^{-1}\right)$ and bovine serum albumin (BSA, $0.5 \mathrm{mg} \mathrm{mL}^{-1}$ ) for $30 \mathrm{~min}$ and then with $\mathrm{KB}$ solution for another $5 \mathrm{~min}$. The $\mathrm{KB}$ solution contained (mmol L ${ }^{-1}$ ): $70 \mathrm{KOH}, 40 \mathrm{KCl}, 3 \mathrm{MgCl}_{2}, 20 \mathrm{KH}_{2} \mathrm{PO}_{4}, 0.5$ EGTA, 50 L-glutamic acid, 20 taurine, 10 HEPES, and 10 glucose ( $\mathrm{pH} 7.4$, adjusted with $\mathrm{KOH}$ ). The ventricles were cut into small chunks and gently agitated in $\mathrm{KB}$ solution. The cells were filtered through nylon mesh and stored in $\mathrm{KB}$ solution at $4^{\circ} \mathrm{C}$.

\subsection{Whole-cell patch clamp technique}

The single-pipette whole-cell patch clamp technique using a patch clamp amplifier (EPC-10 USB; HEKA Electronics, Lambrecht/Pfalz, Germany) was applied to record transmembrane potentials and ion currents at configurations of either a current clamp or a voltage clamp, respectively. A cell suspension of $100 \mu \mathrm{L}$ was transferred to a small chamber mounted on the stage of an inverted microscope and allowed to adhere to the glass bottom of the chamber for $5 \mathrm{~min}$. The cardiomyocytes, characterized by smooth, glossy edges and surfaces and clear transverse striations without contraction were used for this study. Sealing resistance was maintained above $1 \mathrm{G} \Omega$. An $80 \%$ compensation of series resistance was achieved without ringing. Residual linear and capacitance were subtracted using a P/4 leak-subtract protocol.

Currents recorded from cells were filtered at $1 \mathrm{kHz}$, digitized at $10 \mathrm{kHz}$, and saved in a computer hard drive for measurement. All experiments were carried out at room temperature $\left(22-24^{\circ} \mathrm{C}\right)$.

\subsection{Patch clamp on normal and increased $\left[\mathrm{Ca}^{2+}\right]_{i}$}

A whole-cell path clamp technique was used to induce ionic equilibrium between the pipette solution and the intracellular solution. In cells with normal $\left[\mathrm{Ca}^{2+}\right]_{\mathrm{i}}$, both $\mathrm{CaCl}_{2}$ 0.65-1.0 mmol L $\mathrm{m}^{-1}$ and EGTA $10-11 \mathrm{mmol} \mathrm{L}^{-1}$ were used in the pipette solution, and the calculated intracellular $\left[\mathrm{Ca}^{2+}\right]_{\mathrm{i}}$ was $65-100 \mathrm{nmol} \mathrm{L}{ }^{-1}$. The intracellular $\left[\mathrm{Ca}^{2+}\right]_{\mathrm{i}}$ was calculated as follows:

$$
\left[\mathrm{Ca}^{2+}\right]_{\mathrm{p}}=\left(1+k\left([\text { EGTA }]_{\mathrm{p}}+\left[\mathrm{Ca}^{2+}\right]_{\mathrm{i}}\right) \times\left[\mathrm{Ca}^{2+}\right]_{\mathrm{i}}\right) /\left(1+\left[\mathrm{Ca}^{2+}\right]_{\mathrm{i}} \times k\right)
$$

where $\left[\mathrm{Ca}^{2+}\right]_{\mathrm{p}}$ and $[\text { EGTA }]_{\mathrm{p}}$ were the doses added in the pipette solution, respectively, and $k$ was the binding constant between calcium and EGTA. An acutely increased $\left[\mathrm{Ca}^{2+}\right]_{i}$ was obtained by clamping the $\mathrm{Ca}^{2+}$ concentration in the pipette solution at $10^{-6} \mathrm{~mol} \mathrm{~L}^{-1}$ in the absence of EGTA [21].

\subsection{Determination of transmembrane action potentials and ionic currents}

For recording an action potential (AP), the pipette solution contained $\left(\mathrm{mmol} \mathrm{L}^{-1}\right): 120 \mathrm{KCl}, 1 \mathrm{CaCl}_{2}, 5 \mathrm{MgCl}_{2}, 5$ $\mathrm{Na}_{2} \mathrm{ATP}, 11$ EGTA, 10 HEPES, and 10 glucose (pH 7.3, adjusted with $\mathrm{KOH}$ ). The bath solution was the Tyrode solution (see above) containing $1.8 \mathrm{mmol} \mathrm{L}^{-1} \mathrm{CaCl}_{2}$. APs were elicited by depolarizing pulses delivered in a width of $5 \mathrm{~ms}$ and 1.5-fold above the threshold at a rate of $1 \mathrm{~Hz}$.

For recording late $I_{\mathrm{Na}}\left(I_{\mathrm{NaL}}\right)$ at the baseline (normal $\left.\left[\mathrm{Ca}^{2+}\right]_{\mathrm{i}}\right)$, the pipette solution contained $\left(\mathrm{mmol} \mathrm{L}^{-1}\right): 120$ $\mathrm{CsCl}, 1 \mathrm{CaCl}_{2}, 5 \mathrm{MgCl}_{2}, 5 \mathrm{Na}_{2} \mathrm{ATP}, 10 \mathrm{TEACl}, 11$ EGTA, and 10 HEPES ( $\mathrm{pH} 7.3$, adjusted with $\mathrm{CsOH}$ ). The bath solutions contained $\left(\mathrm{mmol} \mathrm{L}{ }^{-1}\right): 135 \mathrm{NaCl}, 1 \mathrm{CaCl}_{2}, 1$ $\mathrm{MgCl}_{2}, 0.05 \mathrm{CdCl}_{2}, 10$ HEPES, 10 glucose (pH 7.4, adjusted with $\mathrm{NaOH}$ ). For recording $I_{\mathrm{NaL}}$ at a condition of in- 
creased $\left[\mathrm{Ca}^{2+}\right]_{\mathrm{i}}, 10 \mathrm{mmol} \mathrm{\textrm {L } ^ { - 1 }}$ EGTA was removed and 1 $\mu \mathrm{mol} \mathrm{L}{ }^{-1} \mathrm{Ca}^{2+}$ was used in the pipette solution. Late $I_{\mathrm{Na}}$ was recorded using 2500-ms voltage steps from a holding potential of -120 to $-30 \mathrm{mV}$ in myocytes. Current density was measured at $200 \mathrm{~ms}$ after depolarization of the cell.

For recording L-type calcium current $\left(I_{\mathrm{CaL}}\right)$ at the baseline (normal $\left[\mathrm{Ca}^{2+}\right]_{\mathrm{i}}$ ), the pipette solution contained $(\mathrm{mmol}$ $\mathrm{L}^{-1}$ ): $80 \mathrm{CsCl}, 60 \mathrm{CsOH}, 40$ aspartic acid, $0.65 \mathrm{CaCl}_{2}, 5$ HEPES, 10 EGTA, $5 \mathrm{MgATP}$, and $5 \mathrm{Na}_{2}$-creatine phosphate ( $\mathrm{pH} 7.2$, adjusted with $\mathrm{CsOH}$ ). For recording L-type calcium current $\left(\mathrm{I}_{\mathrm{CaL}}\right)$ in increased $\left[\mathrm{Ca}^{2+}\right]_{\mathrm{i}}, 10 \mathrm{mmol} \mathrm{L}^{-1}$ EGTA was removed and $1 \mu \mathrm{mol} \mathrm{L}{ }^{-1} \mathrm{Ca}^{2+}$ was used in the pipette solution. The bath solution was the Tyrode solution (see above) containing $50 \mu \mathrm{mol} \mathrm{L} \mathrm{L}^{-1}$ tetrodotoxin (TTX) to block the $I_{\mathrm{Na}}$. $I_{\text {CaL }}$ was determined using voltage-clamp stepped at $300 \mathrm{~ms}$ from a holding potential of $-40 \mathrm{mV}$ to depolarizing levels up to $+60 \mathrm{mV}$ in $10-\mathrm{mV}$ increments at a rate of $0.2 \mathrm{~Hz}$. The current density at a depolarizing test pulse of $+10 \mathrm{mV}$ was measured and analyzed.

For recording $I_{\mathrm{K}}$ at the baseline (normal $\left[\mathrm{Ca}^{2+}\right]_{\mathrm{i}}$ ), the pipette solution contained $\left(\mathrm{mmol} \mathrm{L}^{-1}\right): 60 \mathrm{KOH}, 80 \mathrm{KCl}, 40$ aspartic acid, $0.65 \mathrm{CaCl}_{2}$, $5 \mathrm{HEPES}, 10$ EGTA, $5 \mathrm{MgATP}$, and 5 $\mathrm{Na}_{2}$-creatine phosphate ( $\mathrm{pH} 7.2$, adjusted with $\mathrm{KOH}$ ). For recording $I_{\mathrm{K}}\left(I_{\mathrm{Kr}}\right.$ and $\left.I_{\mathrm{Ks}}\right)$ at increased $\left[\mathrm{Ca}^{2+}\right]_{\mathrm{i}}, 10 \mathrm{mmol} \mathrm{L}{ }^{-1}$ EGTA was removed and $1 \mu \mathrm{mol} \mathrm{L}{ }^{-1} \mathrm{Ca}^{2+}$ was used in the pipette solution. The bath solution for recording $I_{\mathrm{K} 1}$ was the Tyrode solution with $3 \mu \mathrm{mol} \mathrm{L}{ }^{-1}$ nisoldipine to block calcium currents. The bath solution for recording $I_{\mathrm{Kr}}$ and $I_{\mathrm{Ks}}$ was a $\mathrm{Na}^{+}$- and $\mathrm{K}^{+}$-free $N$-methyl-D-glucamine (NMG) solution containing $\left(\mathrm{mmol} \mathrm{L}^{-1}\right)$ : $149 \mathrm{~N}$-methyl-D-glucamine, 5 $\mathrm{MgCl}_{2}, 0.9 \mathrm{CaCl}_{2}, 5$ HEPES (pH 7.4, adjusted with $\mathrm{HCl}$ ), and $3 \mu \mathrm{mol} \mathrm{L}{ }^{-1}$ nisoldipine (to block $I_{\mathrm{ca}}$ ). For recording either $I_{\mathrm{Ks}}$ or $I_{\mathrm{Kr}}, \mathrm{E}-4031$ at $10 \mu \mathrm{mol} \mathrm{L}{ }^{-1}$ and chromanol 293B at $30 \mu \mathrm{mol} \mathrm{L}-1$ were used to block $I_{\mathrm{Kr}}$ and $I_{\mathrm{Ks}}$, respectively.

For $I_{\mathrm{K} 1}$, whole-cell currents were elicited by applying 300-ms hyperpolarizing or depolarizing voltage steps between -100 and $-10 \mathrm{mV}$ in $10-\mathrm{mV}$ increments from a holding potential of $-40 \mathrm{mV}$ to inactivate the sodium channel at a rate of $0.2 \mathrm{~Hz}$. $I_{\mathrm{K} 1}$ was a series of large-amplitude steadystate outward currents with strong rectifier characteristics that could be selectively blocked by $\mathrm{BaCl}_{2}$. The steady-state current density at the end of the clamp pulses was measured at a test pulse of $-80 \mathrm{mV}$, with an approximated resting potential as an index.

$I_{\mathrm{K} \text {-step }}$ was elicited with depolarizing pulses of $1.5 \mathrm{~s}$ from $-40 \mathrm{mV}$ to $+40 \mathrm{mV}$ at a rate of $0.1 \mathrm{~Hz}$. $I_{\mathrm{K} \text {-tail }}$ was measured as an index at a test pulse of $+40 \mathrm{mV}$ when the repolarization current was set back to $-40 \mathrm{mV}$. A combination of E-4031 at $10 \mu \mathrm{mol} \mathrm{L}^{-1}$ and chromanol $293 \mathrm{~B}$ at $30 \mu \mathrm{mol} \mathrm{L}{ }^{-1}$ was used to block $I_{\mathrm{Kr}}$ and $I_{\mathrm{Ks}}$, respectively.

\subsection{Experimental protocols}

Cells were randomized into two groups. Normal $\left[\mathrm{Ca}^{2+}\right]_{\mathrm{i}}$
(65-100 nmol L ${ }^{-1}$ ) was maintained in one group of cells as the control, and another group of cells with $\mathrm{Ca}^{2+}$ in the pipette solution was maintained at $1 \mu \mathrm{mol} \mathrm{L} \mathrm{L}^{-1}$ (increased $\left.\left[\mathrm{Ca}^{2+}\right]_{\mathrm{i}}\right)$. APs and ion currents were recorded every minute for a total of $8 \mathrm{~min}$ in both cell groups.

\subsection{Data analysis}

All data were presented as mean \pm SD and analyzed using FitMaster (v2x32; HEKA) and SPSS 13.0 (SPSS, Chicago, IL, USA). Current density (i.e., amplitude of the current divided by membrane capacitance) was selected for analysis. Figures were plotted by Origin (V7.0; OriginLab, Northampton, MA, USA). Student's $t$-test was used to determine the difference between two groups of data. One-way and two-way analyses of variance (ANOVA) were used to determine the differences of the time-dependent effects. $P \leqslant 0.05$ was considered statistically significant.

\subsection{Drugs and reagents}

Collagenase type I and BSA were purchased from Gibco (Gibco, Invitrogen, Paisley, UK) and Roche (Basel, Switzerland). Tetrodotoxin was provided by Hebei Fisheries Research Institute (Qinhuangdao, China). All other chemicals, including E-4031 and Chromonal 293B, were purchased from Sigma Chemical Co. (St. Louis, MO, USA).

\section{Results}

\subsection{Effects of increased $\left[\mathrm{Ca}^{2+}\right]_{\mathrm{i}}$ on transmembrane ac- tion potentials}

In myocytes under normal $\left[\mathrm{Ca}^{2+}\right]_{\mathrm{i}}(n=15$; Table 1 , Figure $1 \mathrm{~A})$, control values of the resting potential (RMP), AP amplitude (APA), and maximum depolarization velocity $\left(V_{\max }\right)$ were $(-80 \pm 2.5) \mathrm{mV},(120 \pm 8) \mathrm{mV}$, and $(213 \pm 22) \mathrm{V} \mathrm{s}^{-1}$, respectively. The APDs at $90 \%\left(\mathrm{APD}_{90}\right), 50 \%\left(\mathrm{APD}_{50}\right)$, and $30 \%\left(\mathrm{APD}_{30}\right)$ of repolarization were $(317 \pm 27),(270 \pm 23)$,

Table 1 Effect of acute increase in intracellular $\mathrm{Ca}^{2+}$ concentration $\left(\left[\mathrm{Ca}^{2+}\right]_{\mathrm{i}}\right)$ on the parameters of the transmembrane potentials in the ventricular myocytes in guinea pigs ${ }^{\text {a) }}$

\begin{tabular}{|c|c|c|c|c|}
\hline \multirow{2}{*}{$\begin{array}{l}\text { Parameters } \\
\text { Time (min) }\end{array}$} & \multicolumn{2}{|c|}{$\begin{array}{c}\text { Control (normal }\left[\mathrm{Ca}^{2+}\right]_{\mathrm{i}}, \\
n=15)\end{array}$} & \multicolumn{2}{|c|}{$\begin{array}{l}\text { Acutely increased }\left[\mathrm{Ca}^{2+}\right]_{i} \\
(n=11)\end{array}$} \\
\hline & 1 & 5 & 1 & 5 \\
\hline RMP (mV) & $-80 \pm 2.5$ & $-80 \pm 1.6$ & $-78 \pm 1.5^{*}$ & $-67 \pm 3.5^{* * \#}$ \\
\hline $\mathrm{APA}(\mathrm{mV})$ & $120 \pm 8$ & $117 \pm 11$ & $116 \pm 9$ & $98 \pm 5^{* * \#}$ \\
\hline $\mathrm{Vmax}\left(\mathrm{V} \mathrm{s}^{-1}\right)$ & $213 \pm 22$ & $206 \pm 27$ & $201 \pm 18$ & $176 \pm 15^{* * \#}$ \\
\hline $\mathrm{APD}_{90}(\mathrm{~ms})$ & $317 \pm 27$ & $305 \pm 33$ & $235 \pm 22^{* *}$ & $101 \pm 15^{* * \#}$ \\
\hline $\mathrm{APD}_{50}(\mathrm{~ms})$ & $270 \pm 23$ & $266 \pm 28$ & $212 \pm 21^{* *}$ & $73 \pm 14^{* * \#}$ \\
\hline $\mathrm{APD}_{30}(\mathrm{~ms})$ & $202 \pm 19$ & $193 \pm 26$ & $183 \pm 21^{*}$ & $46 \pm 10^{* * \#}$ \\
\hline
\end{tabular}

a) $*, P<0.05 ; * *, P<0.01$, compared with control. \#, $P<0.01$, compared with acutely increased $\left[\mathrm{Ca}^{2+}\right]_{\mathrm{i}}$ at $1 \mathrm{~min}$. 

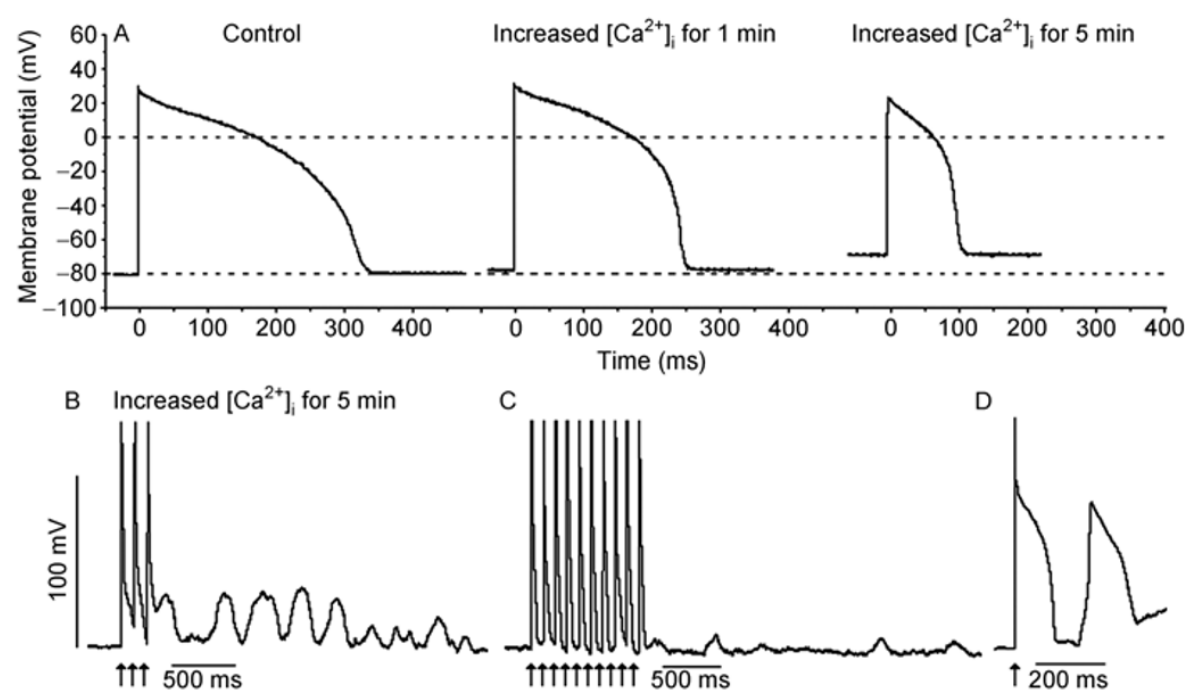

Figure 1 Representative recordings of action potentials (AP) and delayed after depolarizations (DAD) and triggered activities (TA) in cells with either normal (control) or increased intracellular calcium concentration $\left[\mathrm{Ca}^{2+}\right]_{\mathrm{i}}$. APs were recorded from single ventricular myocytes with either normal $\left[\mathrm{Ca}^{2+}\right]_{\mathrm{i}}$ (control, A) or increased $\left[\mathrm{Ca}^{2+}\right]_{i}$ for 1 and $5 \mathrm{~min}(\mathrm{~A})$. DADs and triggered activities were recorded only in cells with increased $\left[\mathrm{Ca}{ }^{2+}\right]_{i}(\mathrm{~B}-\mathrm{D})$. Arrows indicate depolarizing pulse.

and $(202 \pm 19) \mathrm{ms}$, respectively. All of these parameters remained unchanged for a period of 5-8 min.

By contrast, in cells with acutely increased $\left[\mathrm{Ca}^{2+}\right]_{\mathrm{i}}(n=11$; Table 1, Figure 1A), the RMP, APA, and $V_{\max }$ at $1 \mathrm{~min}$ were $(-78.0 \pm 1.5) \mathrm{mV}(P<0.05$ vs. control), $(116 \pm 9) \mathrm{mV}$, and $(201 \pm 18) \mathrm{V} \mathrm{s}^{-1}$, respectively. The RMP, APA, and $V_{\max }$ were significantly reduced, by $18 \%, 18 \%$, and $17 \%$, respectively, at $5 \mathrm{~min}$ compared with that at $1 \mathrm{~min}$ and the control values $\left(n=11, P<0.01\right.$; Table 1, Figure 1). The $\mathrm{APD}_{90}$, $\mathrm{APD}_{50}$, and $\mathrm{APD}_{30}$ were shortened by $26 \%, 21 \%$, and $9 \%$, respectively, at $1 \mathrm{~min}(n=15, P<0.05-0.01$ vs. control and at $1 \mathrm{~min}$ ) and by $68 \%, 73 \%$, and $77 \%$, respectively, at $5 \mathrm{~min}$ $(n=15, P<0.01$; Figure $1 \mathrm{~A})$. All of these parameters reached steady-state after exposure to acutely increased $\left[\mathrm{Ca}^{2+}\right]_{\mathrm{i}}$ for 5 $\min$.

In myocytes exposed to increased $\left[\mathrm{Ca}^{2+}\right]_{i}$, delayed afterdepolarization (DAD) was found in five of 15 cells (33\%), and triggered activity appeared in three of 15 cells (20\%) when the stimulation cycle length was shortened to $100 \mathrm{~ms}$ (Figure 1B-D). DAD and triggered activity were not observed in any of these cells under normal $\left[\mathrm{Ca}^{2+}\right]_{\mathrm{i}}$.

\subsection{Time course of the effects of increased $\left[\mathrm{Ca}^{2+}\right]_{\mathrm{i}}$ on membrane ion currents}

In the cells with normal $\left[\mathrm{Ca}^{2+}\right]_{\mathrm{i}}$ (control), the amplitudes of $I_{\mathrm{NaL}}, I_{\mathrm{CaL}}, I_{\mathrm{K} 1}, I_{\mathrm{Kr}}$, and $I_{\mathrm{Ks}}$ were $(-0.58 \pm 0.05) \mathrm{pA} / \mathrm{pF}(n=7)$, $(-10.85 \pm 1.33) \mathrm{pA} / \mathrm{pF}(n=7),(-14.36 \pm 0.62) \mathrm{pA} / \mathrm{pF}(n=6)$, $(0.48 \pm 0.03) \mathrm{pA} / \mathrm{pF}(n=5)$, and $(1.26 \pm 0.09) \mathrm{pA} / \mathrm{pF}(n=5)$, respectively (Figure 2, control). All these currents remained relatively stable for a period of $8 \mathrm{~min}(P>0.05$; Figure 2 , control).

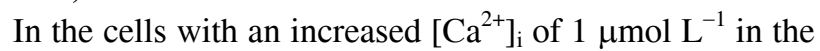

pipette solution, time-dependent consecutive changes in $I_{\mathrm{NaL}}$, $I_{\mathrm{CaL}}, I_{\mathrm{K} 1}$, and $I_{\mathrm{Kr}}$ were observed. The amplitudes of these currents reached steady-state at about $5 \mathrm{~min}$ (Figure 2A-D). At $1 \mathrm{~min}$ after exposure to increased $\left[\mathrm{Ca}^{2+}\right]_{\mathrm{i}}, I_{\mathrm{CaL}}$ was significantly lower than that in the control (Figure 2B). There were significant increases in $I_{\mathrm{NaL}}$ and $I_{\mathrm{Kr}}$, but not in $I_{\mathrm{Ks}}$, and decreases in $I_{\mathrm{CaL}}$ and $I_{\mathrm{K} 1}$ at 2-8 min compared with $1 \mathrm{~min}$ $(P<0.05-0.01)$.

\subsection{Effects of increased $\left[\mathrm{Ca}^{2+}\right]_{\mathrm{i}}$ on membrane ion cur- rents}

Increased $\left[\mathrm{Ca}^{2+}\right]_{\mathrm{i}}$ to $1 \mu \mathrm{mol} \mathrm{L}{ }^{-1}$ significantly enhanced $I_{\mathrm{NaL}}$ from $(-0.60 \pm 0.06) \mathrm{pA} / \mathrm{pF}$ to $(-1.04 \pm 0.08) \mathrm{pA} / \mathrm{pF}$ at $5 \mathrm{~min}$ $(n=7, P<0.01$ compared with either the control or at $1 \mathrm{~min}$; Figures $2 \mathrm{~A}$ and 3 ). Similar to the inhibition of endogenous $I_{\mathrm{NaL}}$ (Figure $3 \mathrm{~A}$, control), $2 \mu \mathrm{mol} \mathrm{L} \mathrm{L}^{-1}$ TTX attenuated the enhanced $I_{\mathrm{NaL}}$ to $(-0.14 \pm 0.02) \mathrm{pA} / \mathrm{pF}(P<0.01$ vs. 5 min of increased $\left[\mathrm{Ca}^{2+}\right]_{i}$; Figure $\left.3 \mathrm{~B}\right)$ in the continuous presence of increased $\left[\mathrm{Ca}^{2+}\right]_{\mathrm{i}}$.

Increased $\left[\mathrm{Ca}^{2+}\right]_{\mathrm{i}}$ decreased $I_{\mathrm{CaL}}$ from $(-10.85 \pm 1.33)$ $\mathrm{pA} / \mathrm{pF}$ to $(-6.35 \pm 0.40) \mathrm{pA} / \mathrm{pF}$ at $1 \min (n=7, P<0.01$ vs. control) and to $(-3.04 \pm 0.29) \mathrm{pA} / \mathrm{pF}$ at $5 \mathrm{~min}(n=7, P<0.01$ vs. both control and $1 \mathrm{~min}$ of increased $\left[\mathrm{Ca}^{2+}\right]_{\mathrm{i}}$; Figures $2 \mathrm{~B}$ and 4).

Increased $\left[\mathrm{Ca}^{2+}\right]_{\mathrm{i}}$ decreased $I_{\mathrm{K} 1}$, with relative decreases of $(-13.76 \pm 0.58) \mathrm{pA} / \mathrm{pF}$ at $1 \mathrm{~min}$ and $(-9.70 \pm 0.18) \mathrm{pA} / \mathrm{pF}$ at 5 $\min (n=8, P<0.01$ vs. both control $(-14.36 \pm 0.63) \mathrm{pA} / \mathrm{pF}$ and 1 min of increased $\left[\mathrm{Ca}^{2+}\right]_{\mathrm{i}}$; Figures $2 \mathrm{C}$ and 5).

In cells with increased $\left[\mathrm{Ca}^{2+}\right]_{\mathrm{i}}, I_{\mathrm{K}}$ was $(1.24 \pm 0.09) \mathrm{pA} / \mathrm{pF}$ at $1 \mathrm{~min}$ and was significantly increased to $(2.03 \pm 0.22) \mathrm{pA} / \mathrm{pF}$ at $5 \mathrm{~min}(n=10, P<0.01$ vs. both the control and increased $\left[\mathrm{Ca}^{2+}\right]_{\mathrm{i}}$ at $1 \mathrm{~min}$; Figure $\left.6 \mathrm{~A}\right)$. Specifically, $I_{\mathrm{Kr} \text {-step }}$ and $I_{\mathrm{Kr} \text {-tail }}$ 

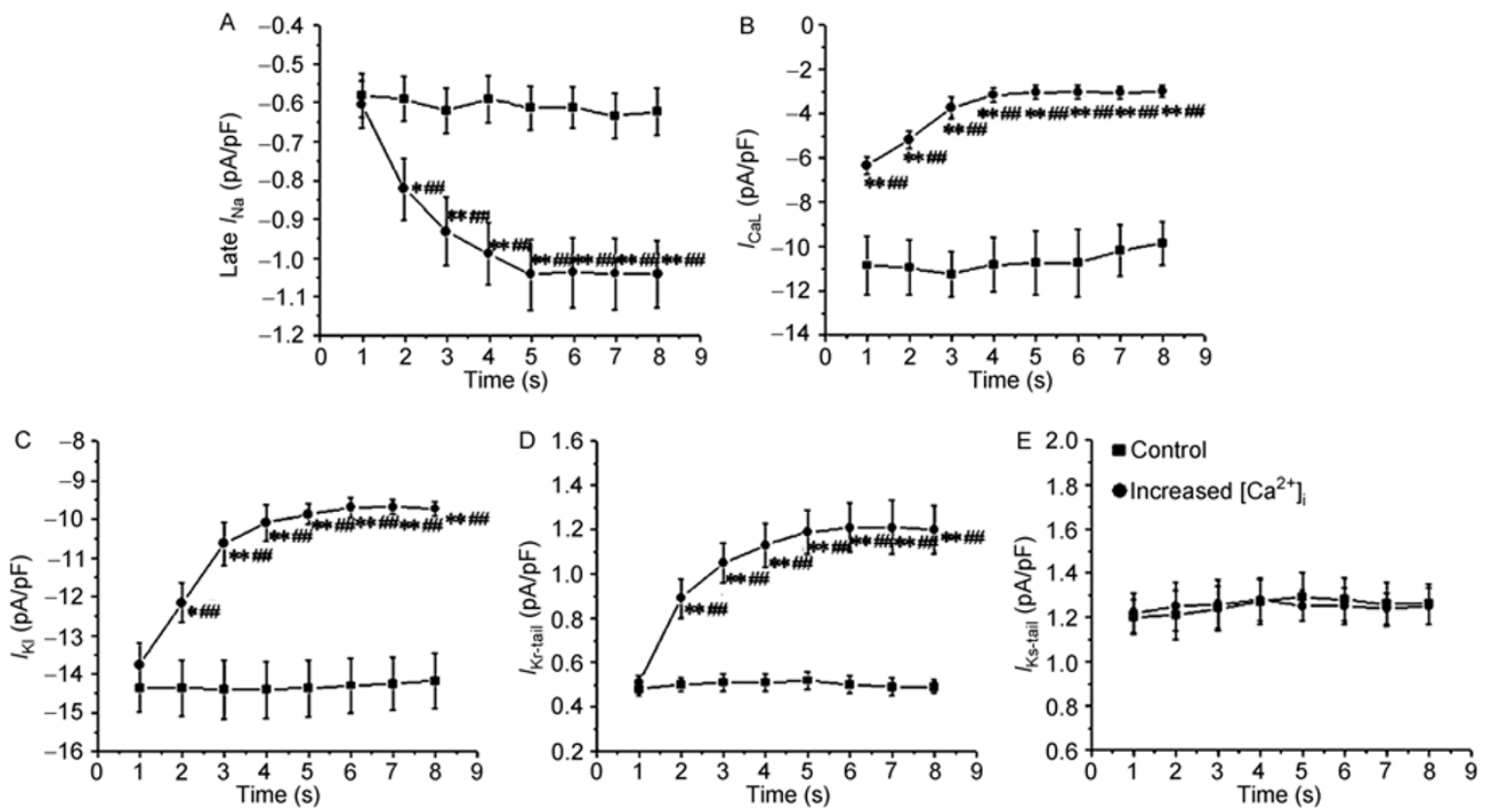

Figure 2 Time-dependent changes of late $I_{\mathrm{Na}}(\mathrm{A}), I_{\mathrm{CaL}}(\mathrm{B}), I_{\mathrm{K} 1}(\mathrm{C}), I_{\mathrm{Kr}}(\mathrm{D})$ and $I_{\mathrm{Ks}}(\mathrm{E})$ in control (normal intracellular calcium) and in cells with increased intracellular $\mathrm{Ca}^{2+}$ concentration $\left(\left[\mathrm{Ca}^{2+}\right]_{\mathrm{i}}\right.$ ) between 1 and $8 \mathrm{~min}$. All currents were recorded continually for $8 \mathrm{~min} .{ }^{*}, P<0.05$; **, $P<0.01$, compared with control. \#, $P<0.05$; \#\#, $P<0.01$, compared with cells with increased $\left[\mathrm{Ca}^{2+}\right]_{\mathrm{i}}$ at $1 \mathrm{~min}$.

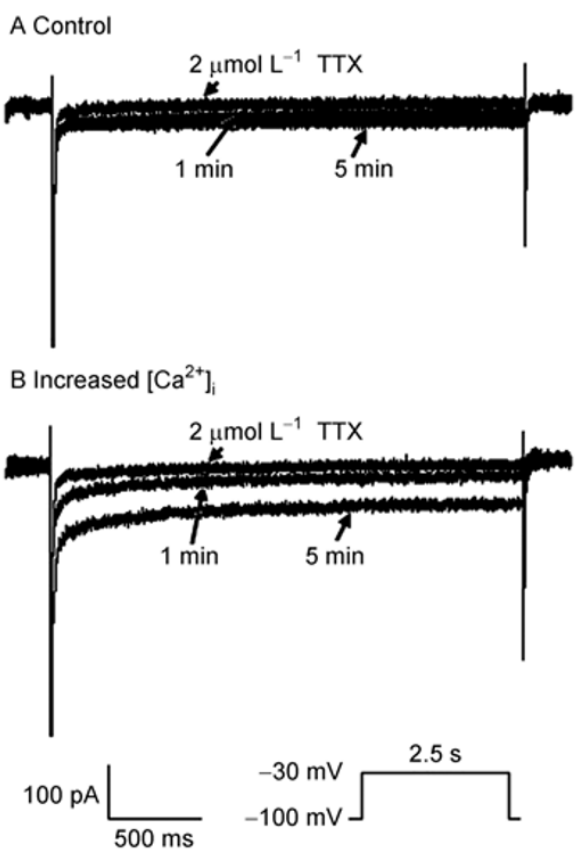

Figure 3 Representative recordings of late $I_{\mathrm{Na}}$ in cells with either normal or acutely increased intracellular $\mathrm{Ca}^{2+}$ concentration $\left(\left[\mathrm{Ca}^{2+}\right]_{\mathrm{i}}\right)$. Late $I_{\mathrm{Na}}$ was recorded from a guinea pig ventricular myocyte exposed to either normal (control, A) or 1 and 5 min after being exposed to increased $\left[\mathrm{Ca}^{2+}\right]_{i}(B)$ in the absence and presence of $2 \mu \mathrm{mol} \mathrm{L} \mathrm{L}^{-1}$ TTX.

were $(0.31 \pm 0.02) \mathrm{pA} / \mathrm{pF}$ and $(0.52 \pm 0.03) \mathrm{pA} / \mathrm{pF}$ at $1 \mathrm{~min}$ $(P>0.05$ vs. control) and $(0.70 \pm 0.04) \mathrm{pA} / \mathrm{pF}$ and $(1.19 \pm$ $0.11) \mathrm{pA} / \mathrm{pF}$ at $5 \mathrm{~min}$, respectively $(n=7, P<0.01 \mathrm{vs}$. both the control and increased $\left[\mathrm{Ca}^{2+}\right]_{\mathrm{i}}$ at $1 \mathrm{~min}$; Figures $2 \mathrm{D}$ and $6 \mathrm{~B}$ ).
By contrast, $I_{\mathrm{Ks}}$ remained unchanged, $I_{\mathrm{Ks} \text {-step }}$ and $I_{\mathrm{Ks} \text {-tail }}$ being $(2.72 \pm 0.19) \mathrm{pA} / \mathrm{pF}$ and $(1.22 \pm 0.09) \mathrm{pA} / \mathrm{pF}$ at $1 \mathrm{~min}$ and $(2.61 \pm 0.21) \mathrm{pA} / \mathrm{pF}$ and $(1.25 \pm 0.08) \mathrm{pA} / \mathrm{pF}$ at $5 \mathrm{~min}$, respectively ( $n=7, P>0.05$ vs. control; Figures $2 \mathrm{E}$ and $6 \mathrm{C}$ ).

\section{Discussion}

Based on the results, we concluded that (i) increased $\left[\mathrm{Ca}^{2+}\right]_{\mathrm{i}}$ decreased RMP, APA, and $V_{\max }$ of an AP and shortened APDs; (ii) multiple ion currents were regulated in cells with increased $\left[\mathrm{Ca}^{2+}\right]_{\mathrm{i}}$, including elevation of $I_{\mathrm{NaL}}$ and $I_{\mathrm{Kr}}$ and reduction of $I_{\mathrm{CaL}}$ and $I_{\mathrm{K} 1}$; (iii) DAD and triggered activity were elicited in cells exposed to increased $\left[\mathrm{Ca}^{2+}\right]_{\mathrm{i}}$. Therefore, intracellular dysregulation of calcium homeostasis may regulate multiple membrane ion currents and cause abnormalities of cellular electrical activity.

Peak $I_{\mathrm{Na}}$ is a major depolarizing current and is associated with the 0 phase of an AP. A recent study indicated that increased $\left[\mathrm{Ca}^{2+}\right]_{\mathrm{i}}$ caused a reduction of peak $I_{\mathrm{Na}}$ owing to the decrease in $\mathrm{Na}^{+}$channel conductance [3]. In the present study, we found that increased $\left[\mathrm{Ca}^{2+}\right]_{\mathrm{i}}$ caused a decrease in APA and $V_{\max }$, which is consistent with previous reports. Maltsev et al. [21] reported that increased $\left[\mathrm{Ca}^{2+}\right]_{\mathrm{i}}$ caused a rightward shift in $I_{\mathrm{Na}}$ in normal and failed hearts. $I_{\mathrm{NaL}}$ was also increased significantly in normal and failing cardiac cells when $\left[\mathrm{Ca}^{2+}\right]_{\mathrm{i}}$ was patched at $1 \mu \mathrm{mol} \mathrm{L}{ }^{-1}$ in the pipette solution, which is consistent with the findings in this study.

Richard et al. [22] demonstrated that increased $\left[\mathrm{Ca}^{2+}\right]_{\mathrm{i}}$ by $\mathrm{SR} \mathrm{Ca}^{2+}$ release caused $\mathrm{Ca}^{2+}$-induced $\mathrm{Ca}^{2+}$ channel inactivation. Consistently, we found that significantly decreased $I_{\mathrm{CaL}}$ 


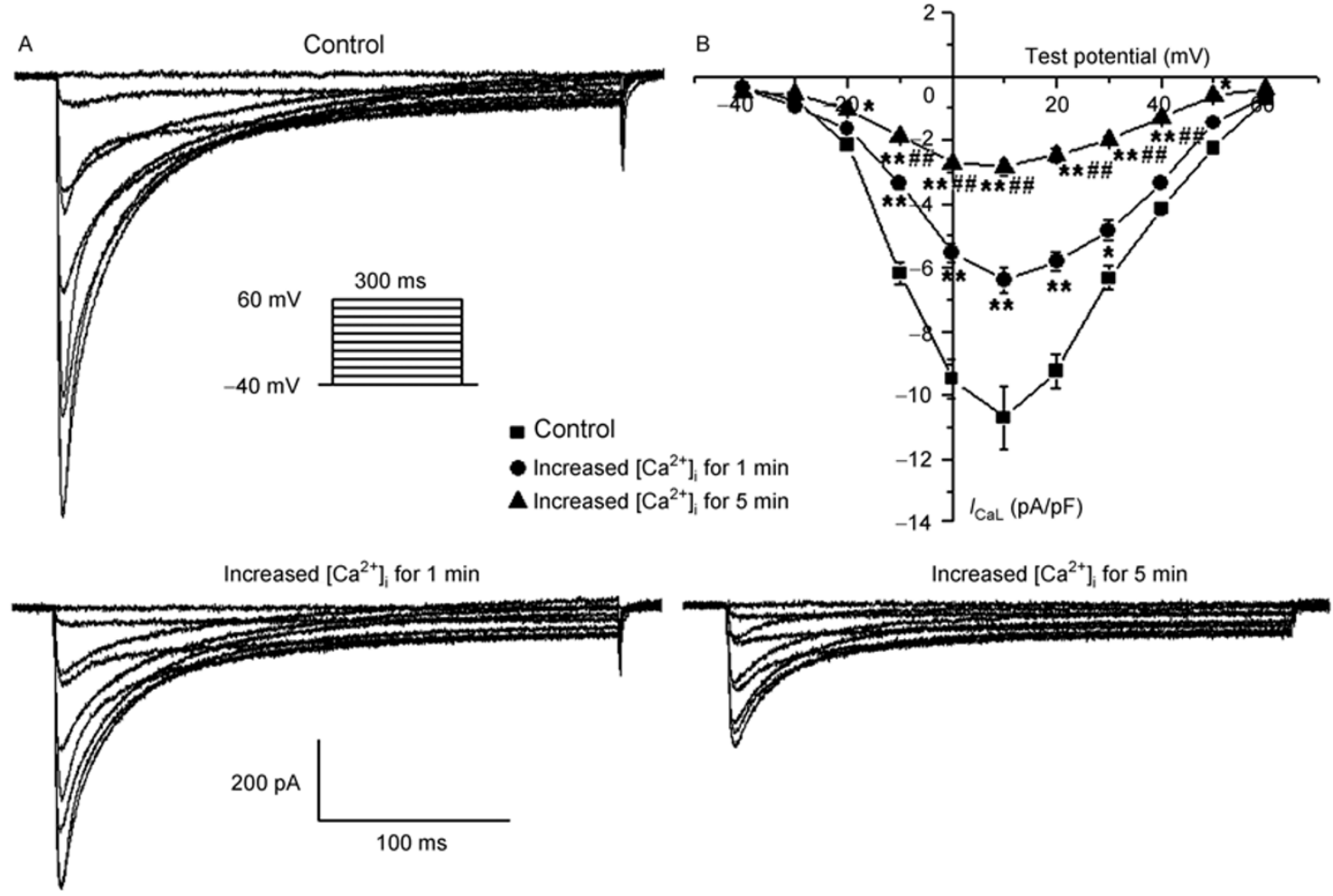

Figure $4 I_{\mathrm{CaL}}$ and its $I-V$ relationships in cells with either normal (control) or increased intracellular $\mathrm{Ca}^{2+}$ concentration $\left(\left[\mathrm{Ca}^{2+}\right]_{\mathrm{i}}\right)$. A, Representative traces of $I_{\mathrm{CaL}}$ in control and increased $\left[\mathrm{Ca}^{2+}\right]_{\mathrm{i}}$ for 1 and $5 \mathrm{~min} . \mathrm{B}, I-V$ relationships of $I_{\mathrm{CaL}}$ in control and increased $\left[\mathrm{Ca}^{2+}\right]_{\mathrm{i}}$ for 1 and 5 min, respectively. *, $P<0.05$; **, $P<0.01$, compared with control. \#, $P<0.05$; \#\#, $P<0.01$, compared with cells with increased $\left[\mathrm{Ca}^{2+}\right]_{\mathrm{i}}$ at $1 \mathrm{~min}$.
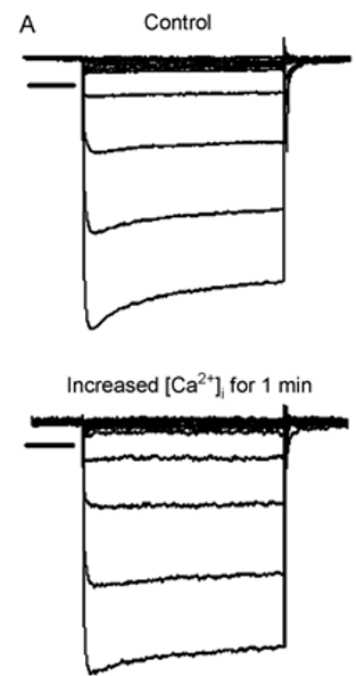
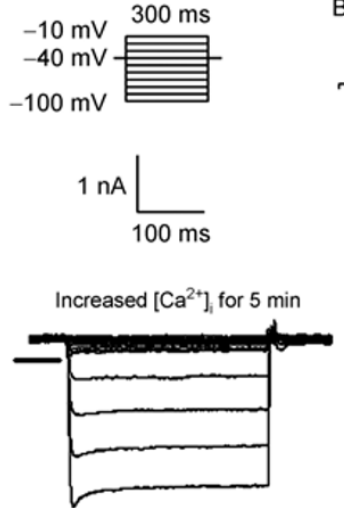

B

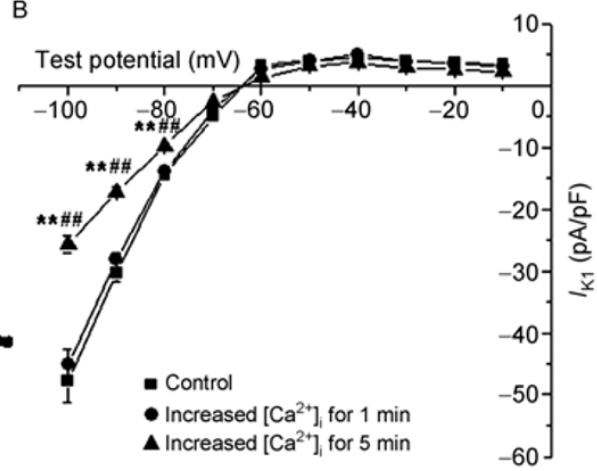

Figure $5 I_{\mathrm{K} 1}$ and its $I-V$ relationships in cells with either normal (control) or increased intracellular $\mathrm{Ca}^{2+}$ concentration $\left(\left[\mathrm{Ca}^{2+}\right]_{\mathrm{i}}\right)$. A, Representative traces of $I_{\mathrm{K} 1}$ in control and increased $\left[\mathrm{Ca}^{2+}\right]_{\mathrm{i}}$ for 1 and $5 \mathrm{~min}$. B. The average $I-V$ curves of $I_{\mathrm{K} 1}$ in control and cells with increased ([Ca $\left.{ }^{2+}\right]_{\mathrm{i}}$. Horizontal bars represent baseline levels. **, $P<0.01$, compared with control. \#\#, $P<0.01$, compared with cells with increased $\left[\mathrm{Ca}^{2+}\right]_{\mathrm{i}}$ at $1 \mathrm{~min}$.

was recorded at the first minute after exposure to high $\left[\mathrm{Ca}^{2+}\right]_{\mathrm{i}}$. Meanwhile, the $I_{\mathrm{Kr}}$ in cells with increased $\left[\mathrm{Ca}^{2+}\right]_{\mathrm{i}}$ was also increased. These changes in $I_{\mathrm{CaL}}$ and $I_{\mathrm{Kr}}$ accelerated the repolarization of ventricular myocytes and shorted the APD. In addition, the significant decrease in $I_{\mathrm{K} 1}$ was recorded after exposure to high $\left[\mathrm{Ca}^{2+}\right]_{\mathrm{i}}$, which may decrease the RMP. In our present research, the variations of multiple ionic currents caused the abnormalities in RMP and AP. Numerous reports have indicated that abnormal cellular electrical activity was found in cells with intracellular cal- 

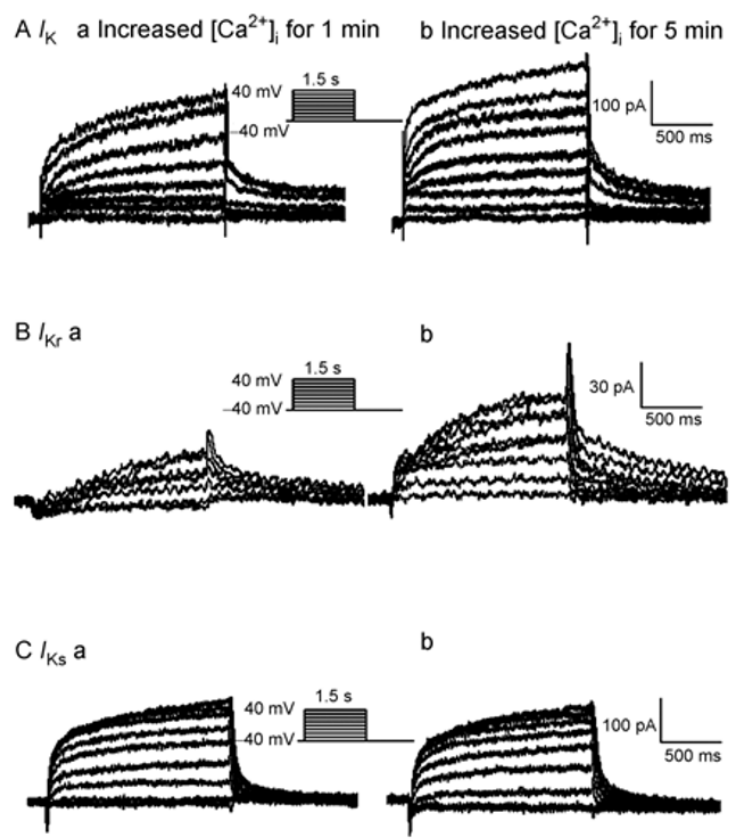
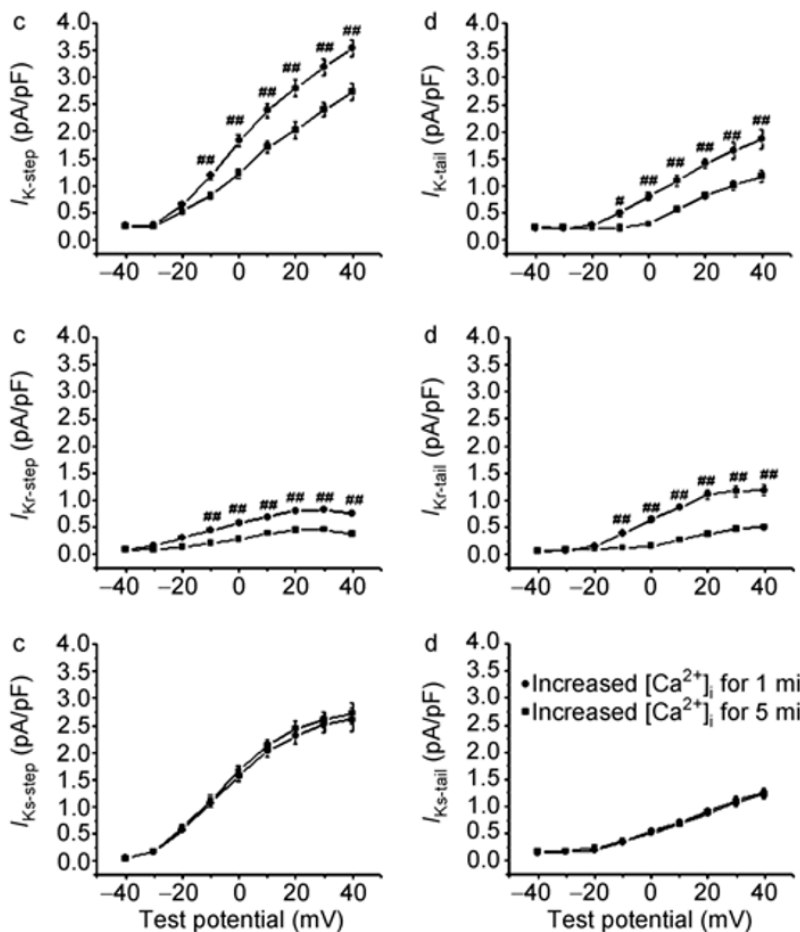

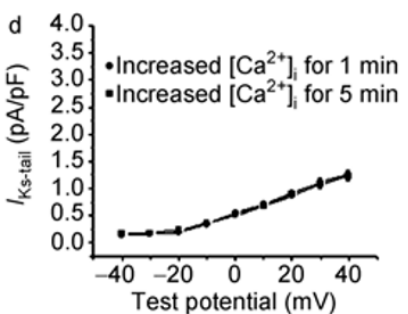

Figure 6 Effects of increased intracellular $\mathrm{Ca}^{2+}$ concentration $\left(\left[\mathrm{Ca}^{2+}\right]_{\mathrm{i}}\right)$ on $I_{\mathrm{K}}(\mathrm{A}), I_{\mathrm{Kr}}(\mathrm{B})$ and $I_{\mathrm{Ks}}(\mathrm{C})$ in guinea pig ventricular myocytes. Representative traces of $I_{\mathrm{K}}, I_{\mathrm{Ks}}$ and $I_{\mathrm{Kr}}$ at 1 (a) and $5 \mathrm{~min}$ (b) after being exposed to increased [ $\left.\mathrm{Ca}^{2+}\right]_{\mathrm{i}} . I-V$ curves for tail current of $I_{\mathrm{K}}, I_{\mathrm{Ks}}$ and $I_{\mathrm{Kr}}$ are shown in panel c of each current, respectively. \#, $P<0.05$; \#\#, $P<0.01$, compared with cells with increased $\left[\mathrm{Ca}^{2+}\right]_{\mathrm{i}}$ at 1 min at each test potential.

cium overload. For example, $I_{\mathrm{CaL}}[23,24]$ and $I_{\mathrm{K} 1}$ [25] were decreased significantly in failed hearts, and increased $\left[\mathrm{Ca}^{2+}\right]_{\mathrm{i}}$ augmented $I_{\mathrm{K}}$ in a concentration-dependent manner $[26,27]$. Clinical use of digitalis [28] or loss of function of the L-type $\mathrm{Ca}^{2+}$ channel in patients with $\mathrm{Ca}^{2+}$ channel (CNCNA) mutations is associated with increased $\left[\mathrm{Ca}^{2+}\right]_{\mathrm{i}}$ and secondary short QT syndrome [29].

As a second messenger, intracellular $\mathrm{Ca}^{2+}$ modulates many ion channels by affecting the intracellular signal transduction mechanism, including gene expression and channel protein synthesis [30]. Elevated intracellular $\mathrm{Ca}^{2+}$ activates $\mathrm{Ca}^{2+} /$ calmodulin-dependent protein kinase II (CaMK II) and protein kinase $\mathrm{C}$ (PKC), and it regulates multiple ion channels including $\mathrm{Na}^{+}, \mathrm{Ca}^{2+}$, and $\mathrm{K}^{+}$channels in the myocardium $[16,18,31,32] . \mathrm{Ca}^{2+}$-induced activation of CaMK II and PKC may be closely related to the increase in SCN5A gene expression and $I_{\mathrm{NaL}}$. Therefore, increased $\mathrm{Ca}^{2+}$ augments $I_{\mathrm{NaL}}$ through an intracellular signal transduction mechanism. An increase in $I_{\mathrm{NaL}}$ caused by increased $\mathrm{Ca}^{2+}$ should prolong the APD [33]. However, the role of increased $\mathrm{I}_{\mathrm{NaL}}$ in APD was offset by the upregulation of $I_{\mathrm{Kr}}$ and the downregulation of $I_{\mathrm{CaL}}$.

Significant up- or downregulation of ion currents in ventricular myocytes causes electrophysiological abnormalities that induce seriously electrical turbulence and the genesis of arrhythmia. Decreased RMP causes increased excitability of myocytes and decreased conduction velocity of ventricular myocardium, which underlies the mechanisms of reentrant arrhythmia. Augmentation of $I_{\mathrm{Kr}}$ and reduction of $I_{\mathrm{CaL}}$ causes abnormal rapid repolarization and shortened APD, which is associated with short QT syndrome, with the shortened refractory period widening cardiac repolarization dispersion. Increased $\left[\mathrm{Ca}^{2+}\right]_{\mathrm{i}}$ also upregulates transient inward currents [34], including the sodium/calcium exchanger current $\left(I_{\mathrm{NCX}}\right)$ [35] and calcium-activated $\mathrm{Cl}^{-}$current [36]. This is likely the cause of the DADs and triggered activity. DADs and triggered activity can cause ectopic ventricular beats and abnormal conduction of an action potential in the heart.

Intracellular calcium overload or increased $\left[\mathrm{Ca}^{2+}\right]_{\mathrm{i}}$ has been demonstrated in many pathological conditions [2-10]. Increased $\left[\mathrm{Ca}^{2+}\right]_{\mathrm{i}}$ augments $I_{\mathrm{NaL}}$. Increased $I_{\mathrm{NaL}}$ increases the intracellular $\mathrm{Na}^{+}$concentration, which further increases the $\left[\mathrm{Ca}^{2+}\right]_{\mathrm{i}}$ by activating the reverse sodium/calcium exchange, thereby forming a vicious circle $[37,38]$. These mechanisms play a role in the genesis of ventricular arrhythmias, even sudden cardiac death. Class III antiarrhythmic agents and ranolazine (an $I_{\mathrm{NaL}}$ inhibitor) are effective in treating calcium overload-induced arrhythmia, suggesting that $I_{\mathrm{NaL}}$ plays an important role in this pathway $[33,39]$.

\section{Conclusion}

Acutely increased $\left[\mathrm{Ca}^{2+}\right]_{\mathrm{i}}$ enhances $I_{\mathrm{NaL}}$ and $I_{\mathrm{Kr}}$ and decreases $I_{\mathrm{CaL}}$ and peak $I_{\mathrm{Na}}$ and $I_{\mathrm{K} 1}$, which are associated with 
reductions of APD, APA, $V_{\max }$, RMP, and arrhythmic activity. These results can be used to explain the calcium overload-induced ventricular arrhythmias in clinical and experimental observations.

This work was supported by the National Natural Science Foundation of China (Grant No. 30870912) and Department of Biology, Gilead Sciences, Inc., USA.

1 Berridge M J. Elementary and global aspects of calcium signalling. J Physiol, 1997, 499: 291-306

2 De Diego C, Pai R K, Chen F, et al. Electrophysiological consequences of acute regional ischemia/reperfusion in neonatal rat ventricular myocyte monolayers. Circulation, 2008, 118: 2330-2337

3 Casini S, Verkerk A O, van Borren M M, et al. Intracellular calcium modulation of voltage-gated sodium channels in ventricular myocytes. Cardiovasc Res, 2009, 81: 72-81

4 Koster O F, Szigeti G P, Beuckelmann D J. Characterization of a $\left[\mathrm{Ca}^{2+}\right]_{\mathrm{i}}$-dependent current in human atrial and ventricular cardiomyocytes in the absence of $\mathrm{Na}^{+}$and $\mathrm{K}^{+}$. Cardiovasc Res, 1999, 41: 175-187

5 Rocchetti M, Besana A, Mostacciuolo G, et al. Diverse toxicity associated with cardiac $\mathrm{Na}^{+} / \mathrm{K}^{+}$pump inhibition: Evaluation of electrophysiological mechanisms. J Pharmacol Exp Ther, 2003, 305: 765-771

6 Shutt R H, Ferrier G R, Howlett S E. Increases in diastolic $\left[\mathrm{Ca}^{2+}\right]$ can contribute to positive inotropy in guinea pig ventricular myocytes in the absence of changes in amplitudes of $\mathrm{Ca}^{2+}$ transients. Am J Physiol Heart Circ Physiol, 2006, 291: H1623-1634

7 Kihara Y, Morgan J P. Intracellular calcium and ventricular fibrillation: Studies in the aequorin-loaded isovolumic ferret heart. Circ Res, 1991, 68: 1378-1389

8 Zaugg C E, Wu S T, Lee R J, et al. Importance of calcium for the vulnerability to ventricular fibrillation detected by premature ventricular stimulation: Single pulse versus sequential pulse methods. J Mol Cell Cardiol, 1996, 28: 1059-1072

9 Lakatta E G, Capogrossi M C, Kort A A, et al. Spontaneous myocardial calcium oscillations: Overview with emphasis on ryanodine and caffeine. Fed Proc, 1985, 44: 2977-2983

10 Song Y, Shryock J C, Wagner S, et al. Blocking late sodium current reduces hydrogen peroxide-induced arrhythmogenic activity and contractile dysfunction. J Pharmacol Exp Ther, 2006, 318: 214-222

11 Xie L H, Chen F, Karagueuzian H S, et al. Oxidative-stress-induced afterdepolarizations and calmodulin kinase II signaling. Circ Res, 2009, 104: 79-86

12 Sipido K R. Calcium overload, spontaneous calcium release, and ventricular arrhythmias. Heart Rhythm, 2006, 3: 977-979

13 Clusin W T. Calcium and cardiac arrhythmias: DADs, EADs, and alternans. Crit Rev Clin Lab Sci, 2003, 40: 337-375

14 Nakajima I, Watanabe $\mathrm{H}$, Iino $\mathrm{K}$, et al. $\mathrm{Ca}^{2+}$ overload evokes a transient outward current in guinea-pig ventricular myocytes. Circ J, 2002, 66: 87-92

15 Wang Y, Tandan S, Cheng J, et al. $\mathrm{Ca}^{2+} /$ calmodulin-dependent protein kinase II-dependent remodeling of $\mathrm{Ca}^{2+}$ current in pressure overload heart failure. J Biol Chem, 2008, 283: 25524-25532

16 Livshitz L M, Rudy Y. Regulation of $\mathrm{Ca}^{2+}$ and electrical alternans in cardiac myocytes: Role of CAMKII and repolarizing currents. Am J Physiol Heart Circ Physiol, 2007, 292: H2854-2866

17 Ho P D, Fan J S, Hayes N L, et al. Ras reduces L-type calcium channel current in cardiac myocytes: Corrective effects of L-channels and SERCA2 on $\left[\mathrm{Ca}^{2+}\right]_{\mathrm{i}}$ regulation and cell morphology. Circ Res, 2001, 88: 63-69

18 Heath B M, Terrar D A. Protein kinase C enhances the rapidly activating delayed rectifier potassium current, $I_{\mathrm{Kr}}$, through a reduction in
C-type inactivation in guinea-pig ventricular myocytes. J Physiol, 2000, 522: 391-402

19 Walsh K B, Zhang J. Neonatal rat cardiac fibroblasts express three types of voltage-gated $\mathrm{K}^{+}$channels: Regulation of a transient outward current by protein kinase C. Am J Physiol Heart Circ Physiol, 2008, 294: H1010-1017

20 McGuigan J A, Luthi D, Buri A. Calcium buffer solutions and how to make them: A do it yourself guide. Can J Physiol Pharmacol, 1991, 69: 1733-1749

21 Maltsev V A, Reznikov V, Undrovinas N A, et al. Modulation of late sodium current by $\mathrm{Ca}^{2+}$, calmodulin, and CaMKII in normal and failing dog cardiomyocytes: Similarities and differences. Am J Physiol Heart Circ Physiol, 2008, 294: H1597-1608

22 Richard S, Perrier E, Fauconnier J, et al. ' $\mathrm{Ca}^{2+}$-induced $\mathrm{Ca}^{2+}$ entry' or how the L-type $\mathrm{Ca}^{2+}$ channel remodels its own signalling pathway in cardiac cells. Prog Biophys Mol Biol, 2006, 90: 118-135

23 Tsuji Y, Opthof T, Kamiya K, et al. Pacing-induced heart failure causes a reduction of delayed rectifier potassium currents along with decreases in calcium and transient outward currents in rabbit ventricle. Cardiovasc Res, 2000, 48: 300-309

24 Mukherjee R, Hewett K W, Spinale F G. Myocyte electrophysiological properties following the development of supraventricular tachycardia-induced cardiomyopathy. J Mol Cell Cardiol, 1995, 27: 1333-1348

25 Fauconnier J, Lacampagne A, Rauzier J M, et al. $\mathrm{Ca}^{2+}$-dependent reduction of IK1 in rat ventricular cells: A novel paradigm for arrhythmia in heart failure? Cardiovasc Res, 2005, 68: 204-212

26 Nitta J, Furukawa T, Marumo F, et al. Subcellular mechanism for $\mathrm{Ca}^{2+}$-dependent enhancement of delayed rectifier $\mathrm{K}^{+}$current in isolated membrane patches of guinea pig ventricular myocytes. Circ Res, 1994, 74: 96-104

27 Klockner U, Isenberg G. Calmodulin antagonists depress calcium and potassium currents in ventricular and vascular myocytes. Am J Physiol, 1987, 253: H1601-1611

28 Cheng T O. Digitalis administration: An underappreciated but common cause of short QT interval. Circulation, 2004, 109: e152

29 Schimpf R, Borggrefe M, Wolpert C. Clinical and molecular genetics of the short QT syndrome. Curr Opin Cardiol, 2008, 23: 192-198

30 Vlasblom R, Muller A, Musters R J, et al. Contractile arrest reveals calcium-dependent stimulation of SERCA2a mRNA expression in cultured ventricular cardiomyocytes. Cardiovasc Res, 2004, 63: 537-544

31 Tohse N, Kameyama M, Sekiguchi K, et al. Protein kinase C activation enhances the delayed rectifier potassium current in guinea-pig heart cells. J Mol Cell Cardiol, 1990, 22: 725-734

32 O-Uchi J, Sasaki H, Morimoto S, et al. Interaction of alpha1-adrenoceptor subtypes with different $\mathrm{G}$ proteins induces opposite effects on cardiac L-type $\mathrm{Ca}^{2+}$ channel. Circ Res, 2008, 102: 1378-1388

33 Zaza A, Belardinelli L, Shryock J C. Pathophysiology and pharmacology of the cardiac "late sodium current". Pharmacol Ther, 2008, 119: 326-339

34 Berlin J R, Cannell M B, Lederer W J. Cellular origins of the transient inward current in cardiac myocytes: Role of fluctuations and waves of elevated intracellular calcium. Circ Res, 1989, 65: 115-126

35 Goldhaber J I. Free radicals enhance $\mathrm{Na}^{+} / \mathrm{Ca}^{2+}$ exchange in ventricular myocytes. Am J Physiol, 1996, 271: H823-833

36 Zygmunt A C, Gibbons W R. Calcium-activated chloride current in rabbit ventricular myocytes. Circ Res, 1991, 68: 424-437

37 Noble D, Noble P J. Late sodium current in the pathophysiology of cardiovascular disease: Consequences of sodium-calcium overload. Heart, 2006, 92: iv1-iv5

38 Levi A J, Dalton G R, Hancox J C, et al. Role of intracellular sodium overload in the genesis of cardiac arrhythmias. J Cardiovasc Electrophysiol, 1997, 8: 700-721

39 Belardinelli L, Shryock J C, Fraser H. Inhibition of the late sodium current as a potential cardioprotective principle: Effects of the late sodium current inhibitor ranolazine. Heart, 2006, 92: iv6-iv14

Open Access This article is distributed under the terms of the Creative Commons Attribution License which permits any use, distribution, and reproduction in any medium, provided the original author(s) and source are credited. 